\title{
HUMAN TISSUE CULTURE STUDIES OF NON-GONOCOCCAL URETHRITIS*
}

\author{
BY \\ DENYS K. FORD \\ Department of Medicine, University of British Columbia, British Columbia Medical Research Institute, Division of \\ Venereal Disease Control, British Columbia Department of Health and Welfare.
}

It has often been suggested that a virus may cause some cases of non-gonococcal urethritis (Harrison and Worms, 1939; Harkness, 1950; Willcox, 1954). The investigation described here was undertaken with the hypothesis that a human-specific virus might be an aetiological agent. In the absence of previous reports of human tissue culture studies of this condition, the following experiments are recorded although no evidence for a virus was obtained.

Hela cells, isolated in 1951 (Gey, Bang, and Gey, 1954) from a carcinoma of the cervix, were selected because methods for handling them are well established and the cells are known to demonstrate a number of widely differing virus groups, poliomyelitis, Coxsackie, arthropod-borne encephalitides, epitheliotropic herpes and vaccinia viruses, and pseudo-lymphocytic choriomeningitis (Syverton and Scherer, 1954). More recently members of the adenoidal - pharyngeal - conjunctival (APC) virus group have caused cytopathogenic changes in Hela cells (Rowe, Hartley, and Huebner, 1956). The plan of the investigation was to collect urethral discharge washings and to add this material to test-tube cultures of Hela cells; these were then observed for the appearance of cytopathogenic changes.

\section{Clinical Material}

Male patients were selected from those attending the Vancouver Venereal Disease Control Clinic in whom routine smears and cultures investigated by the Public Health Laboratory revealed no gonococci. All the cases were examined by the author and gave a history of recent sexual exposure. Additional criteria for inclusion in the study were a visible purulent or semipurulent discharge, a stained smear of which showed moderate to many pus cells and no predominant organism in' marked numbers. In six cases the urethritis seemed from the

\footnotetext{
* Received for publication June 7, 1956.
}

appearance of the smear, to be abacterial, in four cases scattered organisms were seen, and in six a moderate number were present. Cultures for flora other than gonococci were not performed except in Cases 1, 2, and 6, in which staphylococci and diphtheroids were found. Table I (opposite) shows the relevant clinical data of the cases; the varied treatments received by some of the patients before collection of the specimens were disregarded.

After the glans had been cleaned with cetavalon and dried, 5 ml. Hanks' (1949) basic salt solution were injected into the urethra and collected in a sterile test tube. This urethral washing produced an opalescent or cloudy suspension, $0.1 \mathrm{ml}$. of which was inoculated into each Hela culture within 2 hours of collection. The remainder of the specimen was then put into a 5-ml. Kimble glass ampoule, sealed, and stored in an alcohol-dry-ice mixture. In Cases 1, 2, and 6, washings stored for 6-9 weeks were used instead of the fresh material.

\section{Tissue Culture Methods}

Stock cultures were grown in $180-\mathrm{ml}$. Pyrex milk dilution bottles with white rubber stoppers; the nutrient fluid employed was 5 or 10 per cent. calf or human serum in one of the three following synthetic media: Medium $857 \dagger$ (Healy, Fisher, and Parker, 1955) a slight modification of 857 (Medium 1066‡ Connaught Laboratories, 1956), and Eagle's Mediumf (Eagle, 1955). The synthetic media contained $100 \mu \mathrm{g}$. streptomycin and 100 units penicillin $\mathrm{G}$ in each ml. and in addition Media 857 and 1066 contained $0 \cdot 2 \mu \mathrm{g}$. per ml. n-butyl parahydroxybenzoate, a mould inhibitor. All media were gassed with 5 per cent. $\mathrm{CO}_{2}$ in air whenever indicated to adjust the $p \mathrm{H}$ to $7 \cdot 4$. The Hela cells were freed from the floor of the stock bottles using $0 \cdot 1$ per cent. Trypsin (Difco Bacto Trypsin sterile ampoules) in Hanks' basic salt solution at $p \mathrm{H} 7.4$ for 5 to 10 minutes at room temperature. Multiple pipetting resulted in a cell suspension which was

t Obtained from Connaught Medical Research Laboratories, Toronto.

$\ddagger$ Obtained from Microbiological Associates, Inc.. Bethesda, 184 
TABLE I

CLINICAL DATA

\begin{tabular}{|c|c|c|c|c|c|c|c|}
\hline \multirow[b]{2}{*}{$\begin{array}{l}\text { Case } \\
\text { No. }\end{array}$} & \multirow[b]{2}{*}{$\begin{array}{c}\text { Age } \\
(\text { yrs) }\end{array}$} & \multirow[b]{2}{*}{$\begin{array}{l}\text { Number of } \\
\text { Episodes } \\
\text { of Past } \\
\text { Urethritis }\end{array}$} & \multirow{2}{*}{$\begin{array}{l}\text { Number of } \\
\text { Episodes } \\
\text { of Proved } \\
\text { Gonococcal } \\
\text { Urethritis }\end{array}$} & \multicolumn{2}{|c|}{ Approximate Interval } & \multirow{2}{*}{$\begin{array}{l}\text { Number of } \\
\text { Pus Cells } \\
\text { in Smear }\end{array}$} & \multirow[b]{2}{*}{ Bacterial Content of Smear } \\
\hline & & & & $\begin{array}{c}\text { Between Exposure } \\
\text { and Discharge } \\
\text { (days) }\end{array}$ & $\begin{array}{c}\text { Between Onset of } \\
\text { Discharge and } \\
\text { Urethral Washing } \\
\text { (days) }\end{array}$ & & \\
\hline 1 & 56 & 2 & 0 & 3 & 29 & ++ & Moderate number of cocci and bacilli \\
\hline $2^{*}$ & 43 & 9 & $1 * *$ & 12 & 20 & ++ & Moderate number of cocci and bacilli \\
\hline 3 & 24 & 0 & 0 & 30 & 6 & ++ & ? Abacterial \\
\hline 4 & 43 & 2 & $1^{* *}$ & $2-3$ & 19 & $+t+$ & Moderate number of cocci and bacilli \\
\hline 5 & 28 & 1 & 1 & 14 & 12 & $+t+$ & Moderate number of cocci and bacilli \\
\hline 6 & 45 & 3 & 0 & 7 & 11 & $+t+$ & ? Abacterial \\
\hline 7 & 23 & 2 & $\mathbf{0}$ & 16 & 5 & +++ & ? Abacterial \\
\hline 8 & 37 & 0 & 0 & 13 & 25 & ++ & Occasional cocco-bacilli \\
\hline 9 & 30 & 0 & 0 & 26 & 15 & +++ & ? Abacterial \\
\hline 10 & 23 & 9 & 3 & 14 & 11 & +++ & Occasional cocci and bacilli \\
\hline 11 & 32 & 3 & 1 & $3-4$ & 13 & $+t+$ & ? Abacterial \\
\hline 12 & 27 & 2 & 0 & Multiple exposures & 25 & ++ & Occasional cocci and bacilli \\
\hline 13 & 29 & 2 & 1 & 13 & 8 & ++ & Occasional cocci \\
\hline 14 & 26 & 1 & 0 & 11 & 13 & $+t+$ & ? Abacterial \\
\hline 15 & 43 & 2 & 0 & 17 & 9 & +++ & Moderate number of cocco-bacilli \\
\hline 16 & 29 & 0 & 0 & 24 & 3 & ++ & Moderate number of cocci and bacilli \\
\hline
\end{tabular}

* Treated by dilatation for urethral stricture 6 months before.

** Discharge almost certainly gonococcal.

then counted in a haemocytometer. The cell suspension was centrifuged at 1,000 revolutions per minute for 10 minutes and the supernatant trypsin removed. The cell deposit was subcultured by resuspending in sufficient new medium to give a cell count of 100,000 to 200,000 cells per ml., and $1 \mathrm{ml}$. was then distributed to a series of Kimble glass $125 \times 16 \mathrm{~mm}$. screw-cap tubes. The cultures were incubated stationary in an almost horizontal position. The cells had sedimented and become adherent to the glass wall of the tube by the following day and most of the experiments were started on the 3rd to the 6th day after subculture, by which time a uniform sheet of flattened cells was present. Immediately before using these stock tubes for an experiment, each culture was washed three times with $1 \mathrm{ml}$. portions of Hanks' solution, the tubes being almost horizontal and rotated with each wash. One ml. of synthetic medium or this nutrient supplemented with 2 per cent. calf serum was added to the cultures before the inoculum of $0.1 \mathrm{ml}$. of the urethral discharge material was finally introduced. The cultures were observed almost daily by low-power microscopy (16 mm. objective) for 17-19 days, the medium being changed every 3 or 4 days. If the inoculated cultures showed significant degenerative changes, a pool of their nutrient fluid was made and $0.1 \mathrm{ml}$. transferred to additional Hela cultures. These passage experiments consisted of three infected and three control cultures in unsupplemented synthetic medium; they were usually observed for 9 to 12 days but always for an equal time or longer than that which was required for the degeneration to appear in the initial tubes. In all experiments control cultures were included in which no inoculum was added, and in the first five cases additional control tubes were incorporated; these cultures contained $0.1 \mathrm{ml}$. of the urethral discharge inoculum previously heated to $60^{\circ} \mathrm{C}$. for 30 minutes to inactivate the hypothetical virus. Later in the investigation this control for non-specific toxic effects of the urethral discharge material was omitted and any suggestion of significant cellular degeneration was further evaluated by attempting to passage the cytopathogenic agent.

Table II (overleaf) shows the design of each experiment. In Cases 1 and 2, 24 tubes were used, twelve cultures containing 2 per cent. calf serum and twelve the synthetic medium alone. Each set of twelve was subdivided into three groups, the test cultures and the two controls, each with four tubes. In Cases 3, 4, and 5, twelve tubes were used and were subdivided into the same three groups of four tubes; for the first 4 to 6 days of the experiment the cultures grew in synthetic medium alone and this was then supplemented by 2 per cent. calf serum. In Cases 6 to 16 , twelve tubes formed the experiment, six cultures receiving 2 per cent. calf serum and six the synthetic medium without serum; three tubes in each type of medium contained the inoculum and three were controls with nothing added. 
TABLE II

PROCEDURES FOLLOWED IN INDIVIDUAL EXPERIMENTS

\begin{tabular}{|c|c|c|c|c|c|c|c|c|c|c|c|c|c|c|}
\hline \multirow{3}{*}{$\begin{array}{l}\text { Case } \\
\text { No. }\end{array}$} & \multirow{2}{*}{\multicolumn{2}{|c|}{$\begin{array}{l}\text { Urethral } \\
\text { Washings }\end{array}$}} & \multicolumn{6}{|c|}{ Number of Culture Tubes } & \multirow{2}{*}{\multicolumn{2}{|c|}{$\begin{array}{l}\text { Degenerative } \\
\text { Change }\end{array}$}} & \multirow{2}{*}{\multicolumn{2}{|c|}{$\begin{array}{c}\text { Passage } \\
\text { Experiment }\end{array}$}} & \multirow{3}{*}{$\begin{array}{c}\begin{array}{c}\text { Original } \\
\text { Culture }\end{array} \\
\begin{array}{c}\text { No. of } \\
\text { days } \\
\text { Ob- } \\
\text { served }\end{array}\end{array}$} & \multirow{3}{*}{$\begin{array}{c}\begin{array}{c}\text { One } \\
\text { Group in } \\
\text { Synthetic } \\
\text { Medium } \\
\text { Only }\end{array} \\
\begin{array}{c}\text { No. of } \\
\text { days }\end{array}\end{array}$} \\
\hline & & & \multicolumn{2}{|c|}{ Unheated Inoculum } & \multicolumn{2}{|c|}{ Heated Inoculum } & \multicolumn{2}{|c|}{ Nothing Added } & & & & & & \\
\hline & Fresh & Frozen & $\begin{array}{l}\text { Synthetic } \\
\text { Medium }\end{array}$ & $\begin{array}{c}2 \text { per cent. } \\
\text { Calf } \\
\text { Serum }\end{array}$ & $\begin{array}{l}\text { Synthetic } \\
\text { Medium }\end{array}$ & $\begin{array}{c}2 \text { per cent. } \\
\text { Calf } \\
\text { Serum }\end{array}$ & $\begin{array}{l}\text { Synthetic } \\
\text { Medium }\end{array}$ & $\begin{array}{c}2 \text { per cent. } \\
\text { Calf } \\
\text { Serum }\end{array}$ & $\begin{array}{c}\text { Day } \\
\text { Ob- } \\
\text { served }\end{array}$ & $\begin{array}{c}\text { In } \\
\text { Heated } \\
\text { Control }\end{array}$ & $\begin{array}{c}\text { Day of } \\
\text { Pas- } \\
\text { sage }\end{array}$ & $\begin{array}{c}\text { No. of } \\
\text { days } \\
\text { Ob- } \\
\text { served }\end{array}$ & & \\
\hline 1 & - & + & 4 & 4 & 4 & 4 & 4 & 4 & 3 & Yes & 3 & 9 & 19 & 6 \\
\hline 2 & - & + & 4 & 4 & 4 & 4 & 4 & 4 & 4 & No & 4 & 4 & 17 & 9 \\
\hline 3 & + & - & 4 & - & 4 & - & 4 & - & 3 & Yes & 4 & 13 & 4 & 4 \\
\hline 4 & + & - & 4 & - & 4 & - & 4 & - & 5 & Yes & 7 & 12 & 19 & 7 \\
\hline 5 & + & - & 4 & - & 4 & - & 4 & - & 3 & Yes & 4 & 12 & 19 & 4 \\
\hline 6 & - & + & 3 & 3 & - & - & 3 & 3 & 3 & - & 4 & 12 & 19 & 4 \\
\hline 7 & + & - & 3 & 3 & - & - & 3 & 3 & - & - & - & - & 18 & 6 \\
\hline 8 & + & - & 3 & 3 & - & - & 3 & 3 & - & - & - & - & 18 & 9 \\
\hline 9 & + & - & 3 & 3 & - & - & 3 & 3 & - & - & - & - & 18 & 6 \\
\hline 10 & + & - & 3 & 3 & 一 & - & 3 & 3 & - & - & - & - & 18 & 6 \\
\hline 11 & + & - & 3 & 3 & 一 & - & 3 & 3 & - & - & - & 二 & 18 & 6 \\
\hline 12 & + & - & 3 & 3 & - & - & 3 & 3 & - & - & - & - & 18 & 6 \\
\hline 13 & + & - & 3 & 3 & - & - & 3 & 3 & - & - & - & - & 18 & 6 \\
\hline 14 & + & - & 3 & 3 & - & - & 3 & 3 & 4 & - & 7 & 5 & 19 & 7 \\
\hline 15 & + & - & 3 & 3 & - & - & 3 & 3 & - & - & - & - & 19 & 4 \\
\hline 16 & + & - & 3 & 3 & - & - & 3 & 3 & 4 & - & 4 & 9 & 19 & 4 \\
\hline
\end{tabular}

\section{Results}

The Hela cultures in the 2 per cent. calf serum nutrient showed only slight granularity of the cells during the observation period, whereas cultures in unsupplemented synthetic medium showed moderate granularity after 6 to 9 days. It was therefore necessary to change all cultures to 2 per cent. calf serum after about the 6th day, and the last column of Table II shows the length of time that the cultures were kept in synthetic medium alone. This Table also indicates the eight cases in which passage experiments were attempted. In these experiments an apparently significant degenerative change was observed from the 3 rd to the 5th day after inoculation of the cultures in unsupplemented synthetic medium. These changes consisted of rounding-up of some of the cells, variable breaking-up of the epithelial sheet, and increased granularity. They did not occur in the cultures supplied with 2 per cent. calf serum from the start of the experiment, but they were found in the tubes containing heated inoculum in Cases 1, 3, 4, and 5, where such controls were included. In none of the passage experiments was it possible to demonstrate a similar change in the new
Hela cell cultures. In experiments $4,5,6$, and 16 , the cultures having this cellular alteration in the initial tubes were changed to 2 per cent. calf serum and then observed for the full period; the abnormalities were not progressive and the cells subsequently recovered a more healthy appearance.

With the exception of Case 3, originally inoculated tubes were observed for 17 to 19 days. In this experiment, the cellular degeneration was marked in both the unheated and the heated urethral discharge cultures at the end of 4 days. These tubes were discarded and the passage cultures observed up to the 18th day after the beginning of the experiment without the appearance of any abnormality.

A seventeenth experiment had to be excluded from the study because a penicillin and streptomycinresistant diphtheroid was found in the inoculated cultures after the passage of a questionable cytopathogenic agent.

As a positive control of the technique, an APC virus Type 2 was obtained; $0.1 \mathrm{ml}$. of the viral suspension injected into Hela cultures with a similar experimental procedure caused a marked cytopathogenic effect in 3 days. Pooled medium was then 
passaged into five groups of three cultures each at an increasing dilution of $10^{-1}$ to $10^{-5}$. Cellular swelling, breaking-up of the epithelial sheet, and detachment from the glass were observed after 2 to 5 days depending on the inoculum size; in the $10^{-5}$ dilution, this cytopathogenic change was questionable on the 4th day but marked by the 6th day.

\section{Discussion}

A mild non-specific toxic action of the urethral washings would seem to be the probable cause of the degenerative changes already described. This view is supported by the observations that the agent was not passageable, that the appearance was seen also in the cultures containing heated inoculum, and that the change was not progressive on the four occasions when the cultures were further observed. The absence of a significant cytopathogenic effect in the Hela cultures after adding urethral washings does not exclude the possibility that a virus was present. Hela cells do not undergo pathological alterations in the presence of all viruses; for example, only three out of sixteen antigenically distinct Coxsackie viruses produced cytopathogenic changes in Hela cultures (Crowell and Syverton, 1954); moreover, in-vitro, the conditions under which cultures are grown may profoundly affect the response to virus infection (Weller, 1955). For the study of viruses in tissue culture, media entirely devoid of serum from any species are most suitable, because all sera may contain viral inhibitors. In this investigation it was not possible to maintain the Hela cells in synthetic medium alone throughout the whole observation period; as a compromise each experiment contained a group of cultures which received synthetic medium alone until early deterioration required that the nutrient be supplemented with 2 per cent. calf serum.

The sixteen patients studied in the experiments had variable past histories and their clinical and bacteriological findings at the time of inclusion in the series also differed. Nevertheless, the criteria for admission to the study were chosen to select an acute urethritis in which an infective agent might be presumed to be a likely cause. In the absence of other proven aetiological causes, the search for a virus is rational; investigations using different cell types and varying experimental conditions are indicated and some are already in progress.

\section{Summary}

Sixteen selected patients with non-gonococcal urethritis of venereal origin causing a purulent or semipurulent discharge were investigated. Urethral discharge washings inoculated into Hela cell cultures failed to produce any cytopathogenic change suggesting the presence of a virus.

The author wishes to acknowledge the help and encouragement of Dr. R. B. Kerr, Professor and Head of the Department of Medicine, University of British Columbia, and Dr. K. A. Evelyn, Director of the British Columbia Medical Research Institute. He is grateful for the cooperation of the staff of the Venereal Disease Control Clinic. Dr. J. E. Hotchin, Assistant Professor in the Department of Bacteriology and Immunology, University of British Columbia, gave much valuable advice and Mrs. S. Hotchin ably assisted as technician. Dr. R. J. Huebner of the Laboratory of Infectious Diseases, National Microbiological Institute, Bethesda, Maryland, supplied the APC virus, and the Hela cells were obtained from Dr. J. F. Morgan of the Laboratory of Hygiene, Department of National Health and Welfare, Ottawa. The work was supported by Federal Health Grant No. 609-7-16.

\section{REFERENCES}

Crowell, R. L., and Syverton, J. T. (1954). Fed. proc., 13, 489. Eagle, H. (1955). Science, 122, 501. Gey, G. O., Bang, F. B., and

Hanks, J. H. (1949). Proc. Soc. exp. Biol. (N.Y.), 71, 328.

Healy, G. M., Fisher, D. C., and Parker, R. C. (1955). Proc. Soc. exp. Biol. (N.Y. 89, 71 .

Harkness, A. H. (1950). "Non-Gonococcal Urethritis". Livingstone, Edinburgh.

Harrison, L. W., and Worms, W. (1939). British Journal of Venereal Diseases, 15, 237.

Rowe, W. P., Hartley, J. W., and Huebner, R. J. (1956). Proc. Soc. exp. Biol. (N.Y.), 91,260 .

Syverton, J. T., and Scherer, W. F. (1954). Ann. N.Y. Acad. Sci., 58, Art. 7, p. 1056.

Weller, T. H. (1955). Medicine, Baltimore, 34, 1.

Willcox, R. R. (1954). Brit. med. J., 1, 13 . 